\title{
Production of kale seedlings on substrates containing proportions of organic compost
}

\author{
Produção de mudas de couve-folha em substratos contendo proporções de composto orgânico \\ Producción de plántulas de col rizada en sustratos que contienen proporciones de compost orgánico
}

Received: 06/29/2021 | Reviewed: 07/07/2021 | Accept: 07/08/2021 | Published: 07/18/2021

José Luís Trevizan Chiomento ORCID: https://orcid.org/0000-0003-4819-2761

University of Passo Fundo Brazil

E-mail: jose-trevizan@ hotmail.com

Isabel Cristina Lourenço da Silva

ORCID: https://orcid.org/0000-0001-6626-1818

University of Passo Fundo Brazil

E-mail: isabel.agroecologia@gmail.com

Lourival Dantas Fagundes

ORCID: https://orcid.org/0000-0002-9754-0163

University of Passo Fundo Brazil

E-mail: lourivaldfagundes@gmail.com

Rafael Tronco Homrich

ORCID: https://orcid.org/0000-0002-0689-3458 University of Passo Fundo Brazil

E-mail: rafaeltronco@upf.br

Nicolas dos Santos Trentin

ORCID: https://orcid.org/0000-0003-1582-5825

Federal University of Paraná, Brazil

E-mail: ntrentin@gmail.com

Thomas dos Santos Trentin

ORCID: https://orcid.org/0000-0002-9163-5284 University of Passo Fundo Brazil

E-mail: tstrentin@gmail.com

Alana Grando Dornelles

ORCID: https://orcid.org/0000-0001-6680-0885

University of Passo Fundo Brazil

E-mail: alanagrando5@gmail.com

Jéfferson Anzolin

ORCID: https://orcid.org/0000-0002-2113-955X University of Passo Fundo Brazil

E-mail: jeffanzolin@gmail.com

Cláudia Petry

ORCID: https://orcid.org/0000-0002-4187-1449

University of Passo Fundo Brazil

E-mail: petry@upf.br

\begin{abstract}
One of the difficulties in the kale seedlings production in containers is to ensure the production of aboveground biomass with a limited portion of roots, restricted to a small volume of substrate. Thus, we investigated whether substrates with organic compost added to it associated with kale cultivars interfere in the quality of seedlings produced in a greenhouse. Here, we studied two kale cultivars and five substrates. The experiment was designed in randomized blocks, with treatments arranged in a bifactorial scheme $(2 \times 5)$, with three replications. We carried out the physical and chemical characterization of the substrates and evaluated attributes of the aerial part and root system of the kale seedlings. The results showed that the substrate with the highest water retention was the one without the addition of organic compost. The greater the proportion of organic compound added to the substrate, the higher the nitrogen, phosphorus and organic carbon values. Seedlings produced in the substrate with greater water retention capacity had better performance in relation to the morphology of the aerial part and the morphology of the root system. We conclude that seedlings of kale cultivars associated with substrates with higher water retention have better quality. Seedlings of the 'Gaudina' cultivar stand out for their better phytometric morphology, while seedlings of the 'Manteiga' cultivar have higher quality of root biomass.
\end{abstract}

Keywords: Brassica oleracea L. var. acephala DC.; Physical and chemical properties; Phytometric morphology; Organic production of seedlings. 


\section{Resumo}

Uma das dificuldades na produção de mudas de couve-folha em recipientes é o de assegurar a produção de biomassa aérea com porção limitada de raízes, restritas a um pequeno volume de substrato. Assim, investigamos se substratos acrescidos de composto orgânico associados a cultivares de couve-folha interferem na qualidade das mudas produzidas em estufa. Aqui, estudamos duas cultivares de couve-folha e cinco substratos. O experimento foi delineado em blocos casualizados, com os tratamentos arranjados no esquema bifatorial ( 2 x 5), com três repetições. Realizamos a caracterização física e química dos substratos e avaliamos atributos da parte aérea e do sistema radicial das mudas de couve-folha. Os resultados mostraram que o substrato com maior retenção de água foi aquele sem adição de composto orgânico. Quanto maior a proporção de composto orgânico adicionada no substrato maiores os valores de nitrogênio, fósforo e carbono orgânico. Mudas produzidas no substrato com maior capacidade de retenção de água tiveram maior desempenho em relação à morfologia da parte aérea e à morfologia do sistema radicial. Concluímos que mudas de cultivares de couve-folha associada aos substratos com maior retenção hídrica têm melhor qualidade. Mudas da cultivar Gaudina destacam-se pela melhor morfologia fitométrica, enquanto que mudas da cultivar Manteiga apresentam maior qualidade de biomassa radicial.

Palavras-chave: Brassica oleracea L. var. acephala DC.; Propriedades físicas e químicas; Morfologia fitométrica; Produção orgânica de mudas.

\section{Resumen}

Una de las dificultades en la producción de plántulas de col rizada en contenedores es asegurar la producción de biomasa aérea con una porción limitada de raíces, restringida a un pequeño volumen de sustrato. Por lo tanto, investigamos si los sustratos agregados con compost orgánico asociado con cultivares de col rizada interfieren en la calidad de las plántulas producidas en un invernadero. Aquí, estudiamos dos cultivares de col rizada y cinco sustratos. El experimento se diseñó en bloques al azar, con tratamientos dispuestos en un esquema bifactorial ( $2 \times 5)$, con tres repeticiones. Realizamos la caracterización físico-química de los sustratos y evaluamos atributos de la parte aérea y sistema radicular de las plántulas de col rizada. Los resultados mostraron que el sustrato con mayor retención de agua fue el que no tuvo la adición de abono orgánico. Cuanto mayor sea la proporción de compuesto orgánico añadido al sustrato, mayores serán los valores de nitrógeno, fósforo y carbono orgánico. Las plántulas producidas en el sustrato con mayor capacidad de retención de agua tuvieron mejor desempeño en relación a la morfología de la parte aérea y la morfología del sistema radicular. Concluimos que las plántulas de cultivares de col rizada asociadas a sustratos con mayor retención de agua tienen mejor calidad. Las plántulas del cultivar Gaudina destacan por su mejor morfología fitométrica, mientras que las plántulas del cultivar Manteiga presentan mayor calidad de biomasa radicular.

Palabras clave: Brassica oleracea L. var. acephala DC.; Propiedades físicas y químicas; Morfología fitométrica; Producción orgánica de plántulas.

\section{Introduction}

Increasingly, the world's spotlight is focused on functional foods due to the benefits related to preventive health (Skrovankova, et al., 2015). A vegetable that is generally found on the list of healthiest foods is kale (Brassica oleracea L. var. acephala DC.), characterized by leaves that do not form a head (Šamec; Urlić; Salopek-Sondi, 2019). Traditionally, this vegetable is inserted in family farming production systems, in small plots, and is intended for human and/or animal consumption. However, due to the human health benefits arising from the consumption of this horticultural crop (BecerraMoreno, et al., 2013) the demand for kale is increasing.

Thus, adopting technologies that enhance the kale production chain, such as the production of quality seedlings, is a key factor in providing producers with profitability. In horticultural crops, the supply of quality seedlings to producers is important to obtain high production after the establishment of the plants in their cultivation environment (Chiomento, et al., 2019). This quality refers to the robustness of plants against abiotic and biotic stresses (Zhao, et al., 2016). However, a difficulty in the production of seedlings in containers is to ensure the production of aboveground biomass with a limited portion of roots (Lemaire, 1995), restricted to a small volume of substrate, in response to the species/cultivars used.

When cultivating vegetable seedlings for commercial purposes, nurseries should use a growing medium (substrate) with desirable properties to produce good quality seedlings (Oagile, et al., 2016). Due to the cost of acquiring the commercial substrate, it is possible, after having proven its technical efficiency, to use local resources such as substrate conditioners. Handmade organic compounds are an important alternative in this case. Seedlings of leafy vegetable species, such as kale, are strongly dependent on substrate quality and water availability. Substrates can interfere with the development of roots, favoring 
or disfavoring this organ and this compromises the production of aerial biomass of leafy species. To identify these effects, it is essential to take into account the responses to mixtures of conditioners to reduce losses due to negative interactions when using proportions that are unfavorable to production, such as when the substrate becomes denser and with less water retention (Chiomento, et al., 2019).

Substrates often have inconsistent physical properties because their different components are derived from various sources and show different attributes (Lishtvan, et al., 2017). Therefore, choosing an adequate material is essential for the development of plants and this can contribute to reducing the negative effects of ecophysiological stress during the production of seedlings and after their transplantation. An eligible substrate must provide plants with sufficient water and nutrients and allow oxygen to be acquired by the roots (Meng, et al., 2018). In addition, we emphasize that genetic differences are always welcomed in horticulture as they provide different responses to the growing environment in a stressful situation. Plants of the same genus can show different responses when subjected to the same substrate, especially if this material affects the root system produced (Chiomento, et al., 2020).

Due to the fact that the substrate used in the seedling production system is essential for seed germination and plant establishment (Auler, et al., 2015) and that increases in productivity are linked to this input, we proposed to answer the following question: how substrates with organic compost added to it when associated with kale cultivars interfere in the quality of seedlings produced in a greenhouse?

Therefore, based on the hypothesis that the development of seedlings of kale cultivars depends on the water retention of the substrate, here we investigate whether substrates added with organic compost associated with kale cultivars interfere in the quality of the seedlings. Our study provides an insight into the development of kale seedlings using substrates with increasing proportions of organic compost to improve the quality of greenhouse-grown seedlings.

\section{Material and Methods}

\subsection{Plant Material}

The experiment was carried out in the Brazilian subtropics, in the municipality of Passo Fundo (28 $15^{\prime} 46^{\prime \prime} \mathrm{S}, 52^{\circ} 24^{\prime}$ 24” W), Rio Grande do Sul (RS), Brazil, in the fall (April-June) of 2017.

The kale seeds (B. oleracea var. acephala) used in this study were from the 'Gaudina' (dark green, with curled and wavy leaves) and 'Manteiga' (light green, with rounded and large leaves) cultivars.

The materials used as substrates were the commercial substrate Horta $2^{\circledR}$ and a locally prepared compost, based on plant remains from pruning bushes and grass, composted in piles until stabilization (when considering that the residues were fully composted). The composition of Horta $2^{\circledR}$ consists of pine bark, vermiculite, acidity corrector and fertilizers, in quantities not provided by the manufacturer. These two materials were mixed in different proportions and gave rise to five other substrates: $100 \%$ Horta $2^{\circledR}+0 \%$ compost $(100 \mathrm{H} 0 \mathrm{C}), 75 \%$ Horta $2^{\circledR}+25 \%$ compost $(75 \mathrm{H} 25 \mathrm{C}), 50 \%$ Horta $2^{\circledR}+50 \%$ compound (50H 50C), $25 \%$ Horta $2^{\circledR}+75 \%$ compound $(25 \mathrm{H} 75 \mathrm{C})$ and $0 \%$ Horta $2^{\circledR}+100 \%$ compound $(0 \mathrm{H} 100 \mathrm{C})$.

\subsection{Experimental Design}

The treatments, delineated in a bifactorial scheme, consisted of two cultivars of kale ('Gaudina' and 'Manteiga') and five substrates $(100 \mathrm{H} 0 \mathrm{C}, 75 \mathrm{H} 25 \mathrm{C}, 50 \mathrm{H} 50 \mathrm{C}, 25 \mathrm{H} 75 \mathrm{C}$ and $0 \mathrm{H} 100 \mathrm{C})$, arranged in a randomized block design, with three repetitions. Each plot, in each block, consisted of sixteen plants. 


\subsection{Procedures}

The seedlings were produced in expanded polystyrene trays, with dimensions of $0.34 \mathrm{~m}$ in width and $0.68 \mathrm{~m}$ in length. Each tray had 128 cells, with a volume of $35 \mathrm{~cm}^{3}$. On April 20, the trays were filled with substrates $100 \mathrm{H} 0 \mathrm{C}, 75 \mathrm{H} 25 \mathrm{C}, 50 \mathrm{H}$ $50 \mathrm{C}, 25 \mathrm{H} 75 \mathrm{C}$ and $0 \mathrm{H} 100 \mathrm{C}$ and, after that, three seeds (untreated) of the kale cultivars were sown in each cell.

The trays were kept on metal benches, $1.2 \mathrm{~m}$ in relation to the soil surface, in a $90 \mathrm{~m}^{2}$ agricultural greenhouse, with a semicircular roof, installed in the northwest-southeast direction. The galvanized steel frame is covered with a low-density polyethylene film, with an anti-ultraviolet additive and a thickness of 150 microns, and the sides are covered with an anti-aphid screen.

The irrigation used was with sprinklers, in the mechanized system, with a flow of $2 \mathrm{~L} \cdot \mathrm{min}^{-1}$ per unit. The irrigation regime consisted of activating the sprinklers four times a day, with a total wetness of seven minutes. The water depth supplied to the seedlings was $4.35 \mathrm{~mm}$.day ${ }^{-1}$. During the execution of the experiment, through a mini meteorological station, we monitored the average relative humidity of the air, the photosynthetically active radiation and the average air temperature inside the greenhouse, whose average values were $74 \%, 122.25 \mu \mathrm{mol} \mathrm{m}^{-2} \mathrm{~s}^{-1}$ and $17.3^{\circ} \mathrm{C}$, respectively. Regarding seedlings, evaluations started thirty-five days after sowing. Attributes referring to phytometric morphology and seedling quality were evaluated.

\subsection{Physical and Chemical Properties of Substrates}

A $1 \mathrm{~L}$ sample of each substrate was collected and analyzed to obtain physical and chemical attributes of the materials. The physical attributes determined in the substrates were: density (D), total porosity (TP), aeration space (AS), readily available water (RAW) and buffer water (BW) (Brasil, 2007). The chemical attributes determined in the substrates were: nitrogen $(\mathrm{N})$, phosphorus pentoxide $\left(\mathrm{P}_{2} \mathrm{O}_{5}\right)$, potassium oxide $\left(\mathrm{K}_{2} \mathrm{O}\right)$, organic carbon $(\mathrm{OC})$, hydrogen ionic potential $(\mathrm{pH})$, electrical conductivity (EC) and cation exchange capacity (CEC) (Brasil, 2014).

\subsection{Phytometric Morphology}

After germination, we perform the thinning, leaving only one plant per cell in each tray. Thirty-five days after sowing, we measured the height of the aerial part (HAP, $\mathrm{mm}$ ) and the length of the roots (RL, mm) of the seedlings, using a digital caliper. We also evaluated the fresh mass of the aerial part (FMAP, g) and roots (FMR, g) and the dry mass of the aerial part (DMAP, g) and roots (DMR, g). To obtain the dry mass, the seedlings were kept in an oven with forced air circulation, at $65^{\circ} \mathrm{C}$ for 48 hours, until constant mass, weighing in an electronic analytical balance.

\subsection{Seedling Quality}

Seedling quality was obtained by plant development models. These development models are mathematical models that consider plant growth variables (Cournède, et al., 2013), such as shoot morphology and root system morphology attributes. Development models are related to the quality of seedlings, as they refer to the robustness of plants against biotic and abiotic stresses (Zhao, et al., 2016). Thus, the dry matter content of the aerial part (DMCAP) and of the root system (RDMC) was determined, according to Atif, et al. (2016), by the equation:

$\mathrm{DMC}=\left(\frac{\text { dry mass }}{\text { fresh mass }}\right) \times 100$ 


\subsection{Statistical Analysis}

The data obtained were subjected to analysis of variance and, when there was significance, the means of the treatments were compared using the Tukey test, at $5 \%$ probability of error, using the Costat ${ }^{\circledR}$ program.

\section{Results}

\subsection{Physical and Chemical Properties of Substrates}

Regarding the physical characterization of the substrates, our results showed that, due to the density of the materials, the substrate 100H OC is the lightest (Table 1). With the TP, AS, RAW and BW values from Table 1, we made a graph to visualize the relationship between air and water in each substrate (Figure 1). We observed that the materials $100 \mathrm{H} 0 \mathrm{C}$ and $75 \mathrm{H}$ $25 \mathrm{C}$ presented a balanced air-water ratio (Figure 1). The other materials $(50 \mathrm{H} 50 \mathrm{C}, 25 \mathrm{H} 75 \mathrm{C}$ and $0 \mathrm{H} 100 \mathrm{C}$ ) presented an airwater imbalance (Figure 1).

Table 1. Physical characterization of five substrates used in the production of kale seedlings. Passo Fundo, RS, 2017.

\begin{tabular}{|c|c|c|c|c|c|}
\hline \multirow{2}{*}{ Substrates ${ }^{1}$} & $\mathrm{D}^{2}$ & $\mathrm{TP}$ & AS & RAW & BW \\
\hline & $\left(\mathrm{kg} \cdot \mathrm{m}^{-3}\right)$ & \multicolumn{4}{|c|}{$\left(\mathrm{m}^{3} \cdot \mathrm{m}^{-3}\right)$} \\
\hline $100 \mathrm{H} \mathrm{OC}$ & 241 & 0.837 & 0.303 & 0.149 & 0.020 \\
\hline $75 \mathrm{H} 25 \mathrm{C}$ & 268 & 0.819 & 0.299 & 0.154 & 0.018 \\
\hline $50 \mathrm{H} 50 \mathrm{C}$ & 257 & 0.846 & 0.402 & 0.125 & 0.014 \\
\hline $25 \mathrm{H} 75 \mathrm{C}$ & 274 & 0.832 & 0.397 & 0.139 & 0.014 \\
\hline $0 \mathrm{H} 100 \mathrm{C}$ & 305 & 0.837 & 0.400 & 0.153 & 0.013 \\
\hline
\end{tabular}

${ }^{1} 100 \mathrm{H}$ 0C: $100 \%$ Horta $2^{\circledR}+0 \%$ compost; $75 \mathrm{H} 25 \mathrm{C}$ : $75 \%$ Horta $2^{\circledR}+25 \%$ compost; $50 \mathrm{H}$ 50C: $50 \%$ Horta $2^{\circledR}+50 \%$ compost; $25 \mathrm{H} 75 \mathrm{C}$ : $25 \%$ Horta $2^{\circledR}+75 \%$ compost; 0 H 100C: $0 \%$ Horta $2^{\circledR}+100 \%$ compost.

${ }^{2}$ D: density; TP = total porosity; AS: aeration space; RAW: easily available water; BW: buffer water.

Source: Authors' data (2017).

Figure 1. Physical characterization of the substrates used in the study. ${ }^{1} 100 \mathrm{H} 0 \mathrm{C}: 100 \%$ Horta $2^{\circledR}+0 \%$ compost; $75 \mathrm{H} 25 \mathrm{C}$ : $75 \%$ Horta $2^{\circledR}+25 \%$ compost; $50 \mathrm{H}$ 50C: $50 \%$ Horta $2^{\circledR}+50 \%$ compost; $25 \mathrm{H} 75 \mathrm{C}: 25 \%$ Horta $2^{\circledR}+75 \%$ compost; 0H 100C: $0 \%$ Horta $2^{\circledR}+100 \%$ compost. Passo Fundo, RS, 2017.

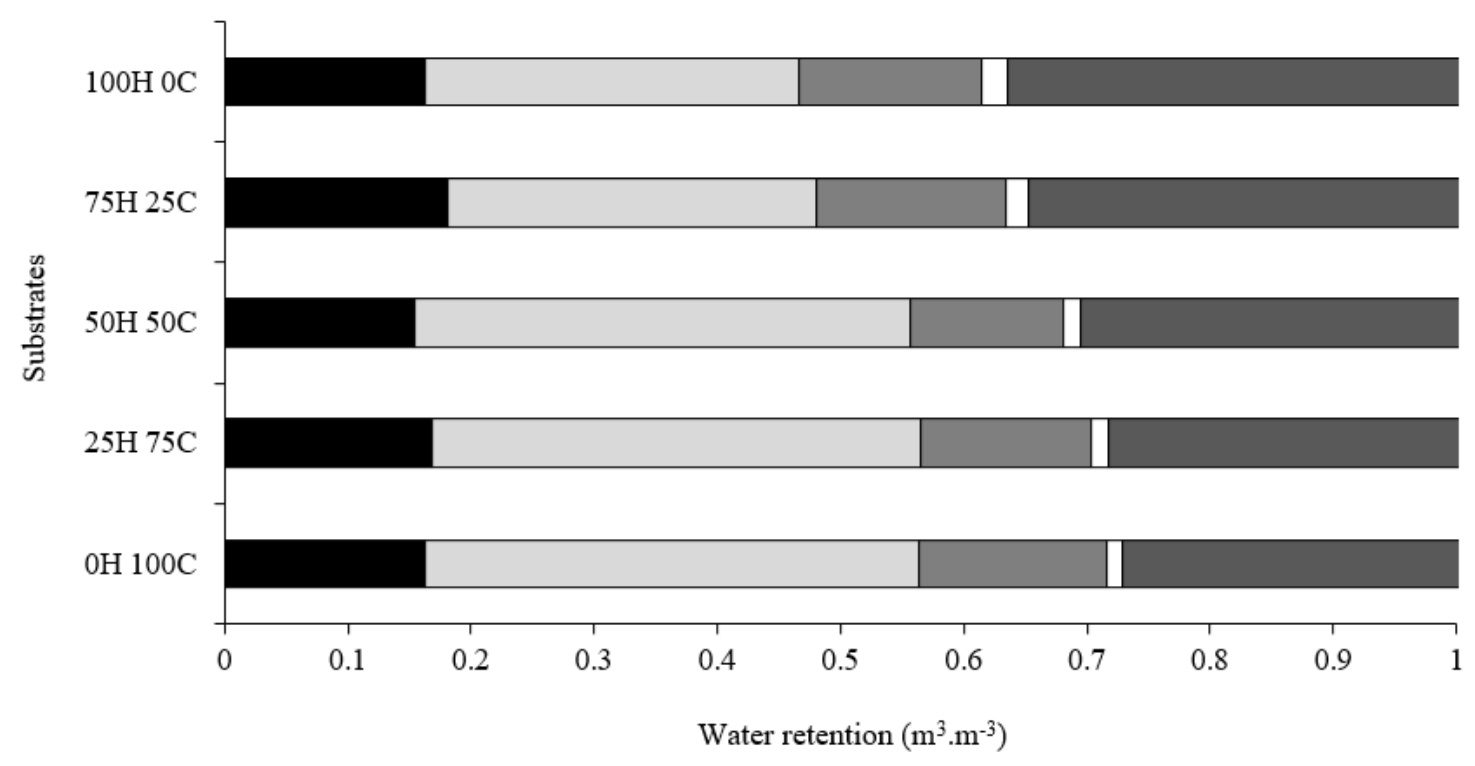

- Solids $\square$ Aeration space $\quad \square$ Easily available water $\quad \square$ Buffering water $\quad \square$ Residual water

Source: Authors' data (2017). 
Still with the values of TP, AS, RAW and BW in Table 1, we made a graph to visualize the water retention curve of each substrate (Figure 2). The $100 \mathrm{H} 0 \mathrm{C}$ and $75 \mathrm{H} 25 \mathrm{C}$ substrates showed higher water retention, requiring volumes of 0.385 $\mathrm{m}^{3} \cdot \mathrm{m}^{-3}$ and $0.366 \mathrm{~m}^{3} \cdot \mathrm{m}^{-3}$, respectively, to remain in the range of readily available water to the plants $\left(10-50-\mathrm{cm} . \mathrm{H}_{2} \mathrm{O}^{-1}\right)($ Figure 2). The substrate $0 \mathrm{H} 100 \mathrm{C}$ had greater water drainage (Figure 2).

Figure 2. Substrates water retention curve. $100 \mathrm{H} 0 \mathrm{C}: 100 \%$ Horta $2^{\circledR}+0 \%$ compost; $75 \mathrm{H} 25 \mathrm{C}: 75 \%$ Horta $2^{\circledR}+25 \%$ compost; $50 \mathrm{H} 50 \mathrm{C}: 50 \%$ Horta $2^{\circledR}+50 \%$ compost; $25 \mathrm{H} 75 \mathrm{C}: 25 \%$ Horta $2^{\circledR}+75 \%$ compost; $0 \mathrm{H} 100 \mathrm{C}: 0 \%$ Horta $2^{\circledR}+100 \%$ compost. Passo Fundo, RS, 2017.

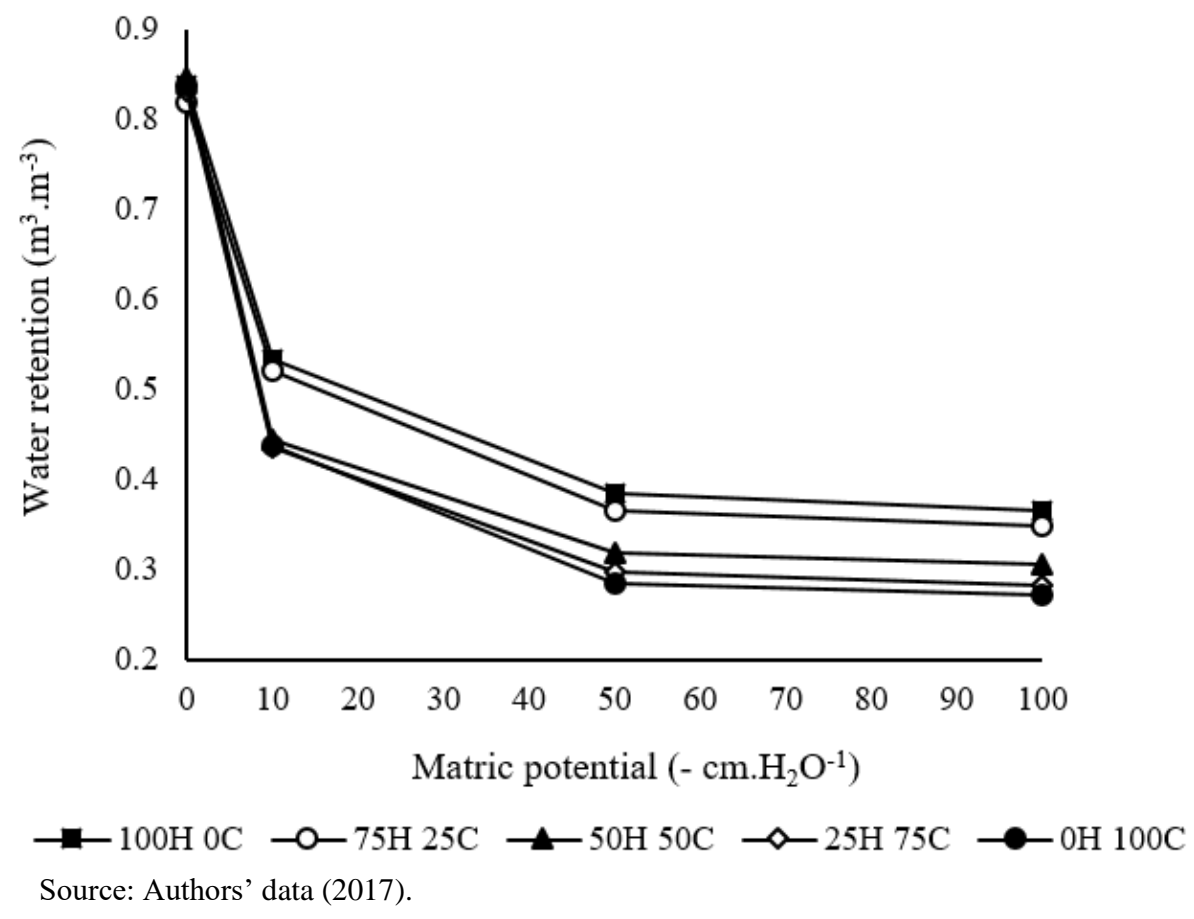

The five materials showed nutrient availability, except for potassium (Table 2). Among the substrates, the higher the proportion of organic compound $(100 \% \mathrm{C})$, the higher the values of $\mathrm{N}_{2}(57 \%), \mathrm{P}_{2} \mathrm{O}_{5}(74 \%)$ and OC $(40 \%)$. The same trend was obtained for electrical conductivity (EC) and cation exchange capacity (CEC), with the substrate being $100 \% \mathrm{C}$ higher (to $0 \%$ C), $20 \%$ higher in EC and $63 \%$ higher in CEC (Table 2).

Table 2. Chemical characterization of five Substrates. Passo Fundo, RS, 2017.

\begin{tabular}{|c|c|c|c|c|c|c|c|}
\hline \multirow{2}{*}{ Substrates $^{1}$} & $\mathrm{~N}^{2}$ & $\mathrm{P}_{2} \mathrm{O}_{5}$ & $\mathrm{~K}_{2} \mathrm{O}$ & $\mathrm{OC}$ & \multirow[t]{2}{*}{$\mathrm{pH}$} & \multirow{2}{*}{$\frac{\mathrm{EC}}{\mathrm{mS} . \mathrm{cm}^{-1}}$} & \multirow{2}{*}{$\frac{\mathrm{CEC}}{\mathrm{mmol}_{\mathrm{c}} \cdot \mathrm{kg}^{-1}}$} \\
\hline & \multicolumn{4}{|c|}{$\%(\mathrm{~m} / \mathrm{m})$} & & & \\
\hline $100 \mathrm{H} \mathrm{OC}$ & 0.69 & 0.39 & 0.00 & 12.60 & 6.1 & 0.45 & 278.60 \\
\hline $75 \mathrm{H} 25 \mathrm{C}$ & 0.62 & 0.65 & 0.00 & 14.27 & 6.3 & 0.68 & 250.11 \\
\hline $50 \mathrm{H} 50 \mathrm{C}$ & 0.99 & 0.88 & 0.00 & 19.09 & 6.4 & 0.66 & 520.86 \\
\hline $25 \mathrm{H} 75 \mathrm{C}$ & 1.05 & 0.72 & 0.00 & 13.32 & 6.6 & 0.69 & 582.20 \\
\hline $0 \mathrm{H} 100 \mathrm{C}$ & 1.62 & 1.52 & 0.00 & 21.11 & 6.6 & 0.58 & 757.62 \\
\hline
\end{tabular}

${ }^{1}$ 100H 0C: $100 \%$ Horta $2^{\circledR}+0 \%$ compost; $75 \mathrm{H} 25 \mathrm{C}: 75 \%$ Horta $2^{\circledR}+25 \%$ compost; $50 \mathrm{H} 50 \mathrm{C}: 50 \%$ Horta $2^{\circledR}+50 \%$ compost; $25 \mathrm{H} 75 \mathrm{C}$ : $25 \%$ Horta $2^{\circledR}+75 \%$ compost; 0H 100C: $0 \%$ Horta $2^{\circledR}+100 \%$ compost.

${ }^{2} \mathrm{~N}$ : nitrogen; $\mathrm{P}_{2} \mathrm{O}_{5}$ : phosphorus pentoxide; $\mathrm{K}_{2} \mathrm{O}$ : potassium oxide; OC: organic carbon; pH: hydrogenic potential; EC: electrical conductivity; CEC: cation exchange capacity.

Source: authors' data (2017). 


\subsection{Phytometric Morphology}

We observed a significant effect for the interaction between substrates and cultivars in relation to the attributes HAP, FMAP and DMAP. The best combination between the studied factors corresponded to the 'Gaudina' cultivar seedlings produced in the substrate $100 \mathrm{H} 0 \mathrm{C}$ for these three attributes (Table 3), but without differing until the use of $75 \%$ of compost ( $25 \mathrm{H} 75 \mathrm{C})$. The most negative responses were when using substrate with $100 \%$ compost ( $0 \mathrm{H} \mathrm{100C)}$. Among the cultivars, we observed that 'Manteiga' in the 75H 25C treatment presented taller seedlings than 'Gaudina', but with lower fresh mass, with no difference in dry mass production in this substrate. With more compost in the substrate ( $75 \%$ and $100 \% \mathrm{C})$, 'Manteiga' produced less DMAP.

Table 3. Association of five substrates and two cultivars of kale regarding shoot morphology of seedlings at 35 days after sowing. Passo Fundo, RS, 2017.

\begin{tabular}{|c|c|c|c|c|c|}
\hline \multirow{3}{*}{ Substrates $^{1}$} & \multicolumn{2}{|c|}{$\mathrm{HAP}(\mathrm{mm})^{2}$} & \multicolumn{3}{|c|}{ FMAP $(g)$} \\
\hline & \multicolumn{2}{|c|}{ Cultivars } & \multicolumn{3}{|c|}{ Cultivars } \\
\hline & 'Gaudina' & 'Manteiga' & 'Gaudina' & & 'Manteiga' \\
\hline $100 \mathrm{H} \mathrm{OC}$ & $117.9 \pm 02.89 \mathrm{Aa}$ & $99.06 \pm 11.65 \mathrm{Aa}$ & $0.57 \pm 0.15 \mathrm{Aa}$ & & $0.42 \pm 0.04 \mathrm{Aa}$ \\
\hline $75 \mathrm{H} 25 \mathrm{C}$ & $91.53 \pm 02.21 \mathrm{Bab}$ & $98.84 \pm 02.68 \mathrm{Ab}$ & $0.43 \pm 0.03 \mathrm{Aa}$ & & $0.30 \pm 0.02 \mathrm{Bb}$ \\
\hline $50 \mathrm{H} 50 \mathrm{C}$ & $91.74 \pm 08.56 \mathrm{Aab}$ & $98.12 \pm 05.39 \mathrm{Ab}$ & $0.51 \pm 0.09 \mathrm{Aa}$ & & $0.44 \pm 0.04 \mathrm{Aa}$ \\
\hline $25 \mathrm{H} 75 \mathrm{C}$ & $86.23 \pm 10.56 \mathrm{Aab}$ & $75.03 \pm 05.16 \mathrm{Ac}$ & $0.48 \pm 0.17 \mathrm{Aa}$ & & $0.17 \pm 0.02 \mathrm{Ac}$ \\
\hline $0 \mathrm{H} 100 \mathrm{C}$ & $66.92 \pm 02.05 \mathrm{Ab}$ & $71.49 \pm 09.82 \mathrm{Ac}$ & $0.18 \pm 0.01 \mathrm{Ab}$ & & $0.13 \pm 0.04 \mathrm{Ac}$ \\
\hline Mean & \multirow{2}{*}{\multicolumn{2}{|c|}{$\begin{array}{l}88.68 \\
06.79\end{array}$}} & \multicolumn{3}{|c|}{0.36} \\
\hline $\mathrm{CV}(\%)^{3}$ & & & \multicolumn{3}{|c|}{18.68} \\
\hline \multirow{3}{*}{ Substrates } & \multicolumn{5}{|c|}{ DMAP $(g)$} \\
\hline & \multicolumn{5}{|c|}{ Cultivars } \\
\hline & 'Gaudina' & & 'Manteiga' & & \\
\hline $100 \mathrm{H} \mathrm{OC}$ & $0.055 \pm 0.01 \mathrm{Aa}$ & & $0.052 \pm 0.01$ & $\mathrm{Aa}$ & \\
\hline $75 \mathrm{H} 25 \mathrm{C}$ & $0.042 \pm 0.02 \mathrm{Aa}$ & & $0.039 \pm 0.01$ & $\mathrm{Ab}$ & \\
\hline $50 \mathrm{H} 50 \mathrm{C}$ & $0.048 \pm 0.01 \mathrm{Aa}$ & & $0.046 \pm 0.02$ & $A a b$ & \\
\hline $25 \mathrm{H} 75 \mathrm{C}$ & $0.049 \pm 0.03 \mathrm{Aa}$ & & $0.019 \pm 0.01$ & $\mathrm{Bc}$ & \\
\hline $0 \mathrm{H} 100 \mathrm{C}$ & $0.018 \pm 0.02 \mathrm{Ab}$ & & $0.015 \pm 0.01$ & $\mathrm{Bc}$ & \\
\hline Mean & & & 0.038 & & \\
\hline $\mathrm{CV}(\%)$ & & & 18.20 & & \\
\hline
\end{tabular}

Data presented as mean \pm standard deviation. Means followed by the same uppercase letter in the row and lowercase letter in the column do not differ significantly by Tukey's test $(\mathrm{p} \leq 0.05)$.

${ }^{1} 100 \mathrm{H} 0 \mathrm{C}: 100 \%$ Horta $2^{\circledR}+0 \%$ compost; $75 \mathrm{H} 25 \mathrm{C}: 75 \%$ Horta $2^{\circledR}+25 \%$ compost; $50 \mathrm{H}$ 50C: $50 \%$ Horta $2^{\circledR}+50 \%$ compost; $25 \mathrm{H} 75 \mathrm{C}$ : $25 \%$ Horta $2^{\circledR}+75 \%$ compost; 0H 100C: $0 \%$ Horta $2^{\circledR}+100 \%$ compost.

${ }^{2}$ HAP: height of the aerial part; FMAP: fresh mass of the aerial part; DMAP: dry mass of the aerial part.

${ }^{3}$ Coefficient of variation.

Source: Authors' data (2017).

We also observed statistical differences for substrates regarding FMR and DMR attributes. Seedlings produced in substrate 100H 0C presented higher FMR and DMR by $72 \%$ and 66\%, respectively, in relation to seedlings developed in substrate $0 \mathrm{H} 100 \mathrm{C}$ (Table 4).

In relation to kale cultivars, significant differences occurred for the attributes RL, FMR and DMR. Seedlings of 'Manteiga' cultivar had a higher RL by $8 \%$ when compared to seedlings of 'Gaudina' cultivar (Table 4). However, seedlings of 'Gaudina' cultivar had higher FMR and DMR by $25 \%$ and $11 \%$, respectively, in relation to those of 'Manteiga' cultivar (Table 4). 
Table 4. Root system morphology of two kale cultivars produced on five substrates at 35 days after sowing. Passo Fundo, RS, 2017.

\begin{tabular}{|c|c|c|c|}
\hline Substrates $^{1}$ & $\mathrm{RL}(\mathrm{mm})^{2}$ & FMR (g) & $\operatorname{DMR}(g)$ \\
\hline $100 \mathrm{H} \mathrm{OC}$ & $109.95 \pm 06.63^{\mathrm{ns}}$ & $0.11 \pm 0.02 \mathrm{a}$ & $0.012 \pm 0.001 \mathrm{a}$ \\
\hline $75 \mathrm{H} 25 \mathrm{C}$ & $104.99 \pm 09.49$ & $0.09 \pm 0.01 \mathrm{~b}$ & $0.010 \pm 0.001 \mathrm{~b}$ \\
\hline $50 \mathrm{H} 50 \mathrm{C}$ & $107.02 \pm 02.65$ & $0.07 \pm 0.02 \mathrm{c}$ & $0.008 \pm 0.002 b c$ \\
\hline $25 \mathrm{H} 75 \mathrm{C}$ & $108.70 \pm 06.38$ & $0.06 \pm 0.02 \mathrm{c}$ & $0.007 \pm 0.001 \mathrm{c}$ \\
\hline $0 \mathrm{H} 100 \mathrm{C}$ & $107.73 \pm 10.86$ & $0.03 \pm 0.01 \mathrm{~d}$ & $0.004 \pm 0.001 \mathrm{~d}$ \\
\hline \multicolumn{4}{|l|}{ Cultivars } \\
\hline 'Gaudina' & $103.53 \pm 14.12 b$ & $0.08 \pm 0.01 \mathrm{a}$ & $0.009 \pm 0.001 \mathrm{a}$ \\
\hline 'Manteiga' & $111.82 \pm 08.29 \mathrm{a}$ & $0.06 \pm 0.01 \mathrm{~b}$ & $0.008 \pm 0.001 \mathrm{~b}$ \\
\hline Mean & 107.68 & 0.07 & 0.008 \\
\hline $\mathrm{CV}(\%)^{3}$ & 5.39 & 12.43 & 10.68 \\
\hline
\end{tabular}

Data presented as mean \pm standard deviation. Means followed by the same letter in the column do not differ significantly by Tukey's test (p5).0.05).

${ }^{1}$ 100H 0C: $100 \%$ Horta $2^{\circledR}+0 \%$ compost; $75 \mathrm{H} 25 \mathrm{C}: 75 \%$ Horta $2^{\circledR}+25 \%$ compost; $50 \mathrm{H} 50 \mathrm{C}: 50 \%$ Horta $2^{\circledR}+50 \%$ compost; $25 \mathrm{H} 75 \mathrm{C}$ : $25 \%$ Horta $2^{\circledR}+75 \%$ compost; 0H 100C: $0 \%$ Horta $2^{\circledR}+100 \%$ compost.

${ }^{2}$ RL: length of roots; FMR: fresh mass of roots; DMR: dry mass of roots.

${ }^{3}$ Coefficient of variation.

${ }^{\text {ns }}$ Not significant.

Source: Authors' data (2017).

\subsection{Seedling Quality}

We observed a significant difference for the interaction between substrates and cultivars in relation to the DMCAP attribute. The best combination of the studied factors corresponded to the seedlings of 'Manteiga' cultivar produced in substrates $100 \mathrm{H} 0 \mathrm{C}$ and $75 \mathrm{H} 25 \mathrm{C}$ (Table 5).

Table 5. Association of five substrates and two cultivars of kale for seedling quality at 35 days after sowing. Passo Fundo, RS, 2017.

\begin{tabular}{|c|c|c|}
\hline \multicolumn{3}{|c|}{$\operatorname{DMCAP}(\%)^{2}$} \\
\hline \multirow{2}{*}{ Substrates $^{1}$} & \multicolumn{2}{|c|}{ Cultivars } \\
\hline & 'Gaudina' & 'Manteiga' \\
\hline $100 \mathrm{H} \mathrm{OC}$ & $09.21 \pm 1.03 \mathrm{Ba}$ & $12.96 \pm 1.14 \mathrm{Aa}$ \\
\hline $75 \mathrm{H} 25 \mathrm{C}$ & $09.69 \pm 1.78 \mathrm{Ba}$ & $12.91 \pm 1.13 \mathrm{Aa}$ \\
\hline $50 \mathrm{H} 50 \mathrm{C}$ & $09.12 \pm 1.05 \mathrm{Aa}$ & $10.50 \pm 1.04 \mathrm{Ab}$ \\
\hline $25 \mathrm{H} 75 \mathrm{C}$ & $10.18 \pm 1.42 \mathrm{Aa}$ & $11.22 \pm 1.07 \mathrm{Ab}$ \\
\hline $0 \mathrm{H} 100 \mathrm{C}$ & $10.03 \pm 2.29 \mathrm{Aa}$ & $10.91 \pm 1.11 \mathrm{Ab}$ \\
\hline Mean & \multicolumn{2}{|c|}{10.68} \\
\hline $\mathrm{CV}(\%)^{3}$ & \multicolumn{2}{|c|}{7.60} \\
\hline
\end{tabular}

Data presented as mean \pm standard deviation. Means followed by the same uppercase letter in the row and lowercase letter in the column do not differ significantly by Tukey's test $(\mathrm{p} \leq 0.05)$.

${ }^{1} 100 \mathrm{H} 0 \mathrm{C}: 100 \%$ Horta $2^{\circledR}+0 \%$ compost; $75 \mathrm{H} 25 \mathrm{C}: 75 \%$ Horta $2^{\circledR}+25 \%$ compost; $50 \mathrm{H} 50 \mathrm{C}: 50 \%$ Horta $2^{\circledR}+50 \%$ compost; $25 \mathrm{H} 75 \mathrm{C}$ :

$25 \%$ Horta $2^{\circledR}+75 \%$ compost; 0H 100C: $0 \%$ Horta $2^{\circledR}+100 \%$ compost.

${ }^{2}$ DMCAP: dry matter content of the aerial part.

${ }^{3}$ Coefficient of variation.

Source: Authors' data (2017).

Furthermore, we observed statistical differences for cultivars in relation to the RDMC attribute. Seedlings of 'Manteiga' cultivar had 9\% higher RDMC compared to seedlings of 'Gaudina' cultivar (Figure 3). 
Figure 3. Root dry matter content (RDMC) of seedlings of two kale cultivars produced in substrates at 35 days after sowing. Data presented as mean \pm standard deviation. Means followed by the same letter in the bars do not differ significantly by Tukey’s test ( $\mathrm{p} \leq 0.05)$. Passo Fundo, RS, 2017.

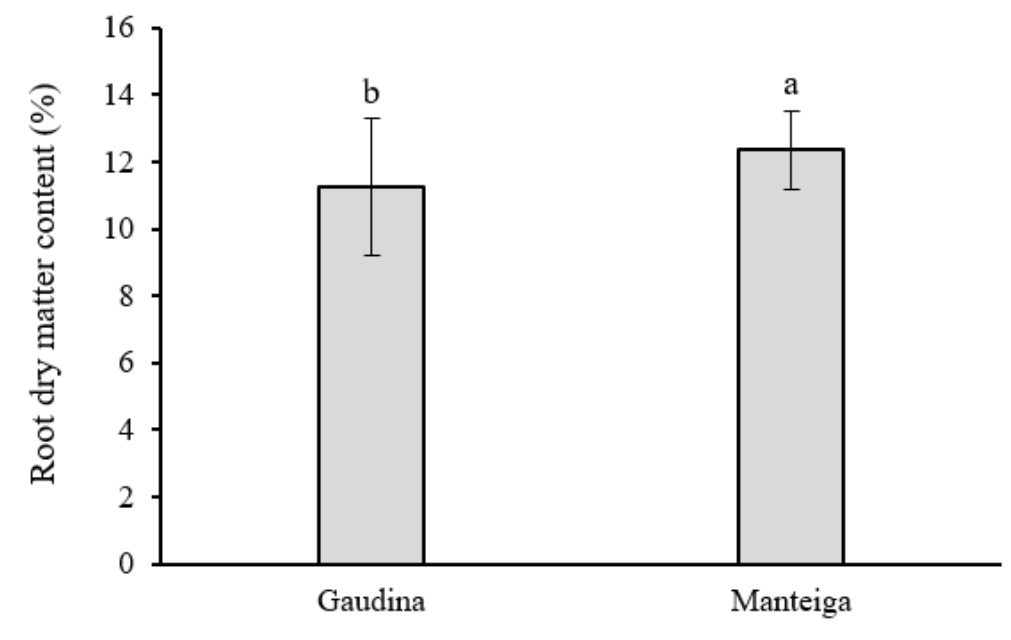

Source: Authors' data (2017).

\section{Discussion}

Here, we show that the quality of seedlings of kale cultivars was associated with the types of substrate studied. We proved that substrates with greater water retention enhanced the growth and development of seedlings. Thus, the physical characterization of the substrates used in the production of seedlings makes it possible to select materials with greater water availability, in order to increase the quality of the seedlings produced and establish adequate management to enhance the production chain of kale. When analyzing the studied genotypes, we verified that 'Gaudina' cultivar had better phytometric morphology and 'Manteiga' cultivar had the highest quality of root biomass.

Kale, due to its morphological characteristics of investing in the formation of larger leaves, requires greater availability of water, both for production and for maintaining the turbidity of these leaves. Therefore, the higher quality of the seedlings produced at 100H OC (Tables 3, 4 and 5) was attributed to the greater availability of water for this material (Figure 2), as the water retention capacity of the substrates influences the growth and development of the seedlings (Graceson, et al., 2013). As in our study, other studies showed greater growth and development of seedlings produced on substrates with greater water retention (Chiomento, et al., 2019; Chiomento, et al., 2020).

The availability of water from a substrate is related to its retention and release and its volume available to plants under low tension (Bunt, 1961). The more water available at low tensions, the less energy the plant demands to use it (Fermino; Kämpf, 2012). Thus, the greater the water storage capacity at low tensions, as observed at 100H 0C (Figure 2), the greater the water savings and the lower the costs with irrigation and fertilization, as frequent irrigation can lead to a more pronounced leaching of nutrients.

Although the substrate with the highest percentage of compost (OH 100C) had the highest nutrient and CEC contents (Table 2), this did not mean improvements for the seedlings, as in this material we observed lower effects on the seedlings, both in the aerial part (Table 3) as in the roots (Table 4). This could be due to the greater presence of phosphorus in the organic form. We emphasize that it is not possible to distinguish organic and inorganic phosphorus in the analysis performed (Table 2). Therefore, even though the $0 \mathrm{H} 100 \mathrm{C}$ material had higher phosphorus contents, possibly this nutrient was in its organic form.

The mineralization process is responsible for the absorption of nutrients by plants, releasing orthophosphate anions ( $\mathrm{HPO}_{4}^{-2}$ or $\mathrm{H}_{2} \mathrm{PO}_{4}{ }^{-}$) in the substrate solution, as it is the form of absorption by plant roots (Richardson, et al., 2009). Possibly, 
the commercial substrate (100H 0C) has inorganic phosphorus in its composition, supplied via fertilizers, which makes the phosphorus readily available in the solution for absorption by plants. As the production of kale seedlings is a quick step, plants grown in the commercial substrate had greater access to phosphorus. Thus, the limiting conditions of this nutrient at $0 \mathrm{H} 100 \mathrm{C}$ may have contributed to reducing the height and dry mass of seedlings (Huang, et al., 2002). This material (0H 100C) was the substrate that presented the lowest water retention (Figure 2) and the lowest residual water (Figure 1), but the highest density and largest aeration space (Table 1), not differing in porosity. These combined physical characteristics did not allow for the good development of the seedlings.

We observed differences between cultivars, which are attributed to genetic issues. The 'Manteiga' cultivar, even with lower FMAP when produced in the substrate $75 \mathrm{H} 25 \mathrm{C}$, did not differ from the 'Gaudina' cultivar in the production of DMAP (Table 3) and presented longer roots with lower fresh and dry mass (Table 4). This made the quality of seedlings of 'Manteiga' cultivar, verified by DMCAP (Table 5) and by RDMC (Figure 3), superior than the ones from 'Gaudina' cultivar. It is almost a compensation of the root system in relation to the lower height of the aerial part.

\section{Conclusion}

The quality of seedlings of kale cultivars is associated with the types of substrate studied. We proved that substrates with greater water retention promote greater growth and development of seedlings. In addition, we show that the cultivar Gaudina stands out for its better phytometric morphology, while the cultivar Manteiga has higher quality of root biomass. We suggest that nurseries do not use organic compost alone as a substrate and that prior to the production of seedlings, carry out physical analysis of the substrates, selecting materials with greater availability of water in order to establish adequate irrigation management to enhance the production chain of kale.

\section{Acknowledgments}

To the Post-Graduate Support Program for Private Community Education Institutions (PROSUC) of the Coordination for the Improvement of Higher Education Personnel (CAPES), for granting the scholarship, and to the Post-Graduate Program in Agronomy (PPGAgro), of the University of Passo Fundo (UPF), for the human resources training. We inform you that this study was financed in part by the Coordination for the Improvement of Higher Education Personnel - Brazil (CAPES) Financial Code 001.

\section{References}

Atif, M. J., Jellani, G., Malik, M. H. A., Saleem, N., Ullah, H., Khan, M. Z., \& Ikram, S. (2016). Different growth media effect the germination and growth of tomato seedlings. Science, Technology and Development, 35 (3), 123-127.

Auler, A. C., Galetto, S. L., Silva, A. R., \& Verona, R. B. (2015). Lettuce seedlings development index in different substrates using multivariate analysis. Científica, 43 (1), 50-57.

Becerra-Moreno, A., Alanís-Garza, P. A., Mora-Nieves, J. L., Mora-Mora, J. P., \& Jacobo-Velázquez, D. A. (2013). Kale: An excellent source of vitamin C, pro-vitamin A, lutein and glucosinolates. CyTA - Journal of Food, 12, 298-303.

Brasil. (2007). Instrução normativa n. 17, de 21 de maio de 2007: aprova os métodos analíticos oficiais para análise de Substrates e condicionadores de solos e revoga a Instrução Normativa n. 46, de 12 de setembro de 2006. Diário Oficial da União, Brasília, n. 99, Seção 1, p. 8.

Brasil. (2014). Ministério da Agricultura, Pecuária e Abastecimento. Manual de métodos analíticos oficiais para fertilizantes minerais, orgânicos, organominerais e corretivos / Ministério da Agricultura, Pecuária e Abastecimento. Secretaria de Defesa Agropecuária. Coordenação-Geral de Apoio Laboratorial; Murilo Carlos Muniz Veras (Org.) - Brasília: MAPA/SDA/CGAL. 220 p.

Bunt, A. C. (1961). Some physical properties of pot-plant composts and their effect on plant growth. Plant and Soil, 13 (4), $322-332$.

Chiomento, J. L. T., Cavalli, G. O., Trentin, T. S., \& Dornelles, A. G. (2020). Quality of tomato seedlings produced in substrates. Pesquisa Agropecuária Gaúcha, 26 (1), 319-331. 
Research, Society and Development, v. 10, n. 8, e58010817707, 2021

(CC BY 4.0) | ISSN 2525-3409 | DOI: http://dx.doi.org/10.33448/rsd-v10i8.17707

Chiomento, J. L. T., Frizon, P., Costa, R. C., Trentin, N. S., De Nardi, F. S., \& Calvete, E. O. (2019). Water retention of substrates potentiates the quality of lettuce seedlings. Advances in Horticultural Science, 33 (2), 197-204.

Cournède, P. H., Chen, Y., Wu, Q., Baey, C., \& Bayol, B. (2013). Development and evaluation of plant growth models: methodology and implementation in the PYGMALION platform. Mathematical Modelling of Natural Phenomena, 8 (4), 112-130.

Fermino, M. H., \& Kämpf, A. N. (2012). Density of substrates depending on the analytical methods and the levels of humidity. Horticultura Brasileira, 30 (1), 75-79.

Graceson, A., Hare, M., Monaghan, J., \& Hall, N. (2013). The water retention capabilities of growing media for green roofs. Ecological Engineering, 61, 328334.

Huang, J. S., Nelson, P. V., Bailey, D. A., Fonteno, W. C., \& Mingis, N. C. (2002). Assessment of the need for nitrogen, phosphorus, potassium, and sulfur preplant nutrients for plug seedling growth. HortScience, 37 (3), 529-533.

Lemaire, F. (1995). Physical, chemical and biological properties of growing medium. Acta Horticulturae, 396, $273-284$.

Lishtvan, I. I., Mulyarchik, V. V., Tomson, A. E., Kurzo, B. V., Naumova, G. V., Zhmakova, N. A., Tsaryuk, T. Y., Sokolova, T. V., Makarova, N. L., Ovchinnikova, T. F., Sosnovskaya, N. E., Pekhtereva, V. S., Navosha, Y. Y., \& Kalilets, L. P. (2017). A study of the composition and properties of peat from the Turshovka-Chertovo deposit as a raw material for deep complex processing. Solid Fuel Chemistry, 51, 286-295.

Meng, X., Dai, J., Zhang, Y., Wang, X., Zhu, W., Yuan, X., Yuan, H., \& Cui, Z. (2018). Composted biogas residue and spent mushroom substrate as a growth medium for tomato and pepper seedlings. Journal of Environmental Management, 216, 62-69.

Oagile, O., Ramalekane, O., Mojeremane, W., Matsuane, C., Legwaila, G. M., \& Mathowa, T. (2016). Growth and development response of kale (Brassica oleracea var. acephala L.) seedlings to different commercial growing media. International Journal of Plant \& Soil Science, 12 (4), 1-7.

Richardson, A. E., Hocking, P. J., Simpson, R. J., \& George, T. S. (2009). Plant mechanisms to optimise access to soil phosphorus. Crop and Pasture Science, 60 (2), 124-143.

Šamec, D., Urlić, B., \& Salopek-Sondi, B. (2019). Kale (Brassica oleracea var. acephala) as a superfood: Review of the scientific evidence behind the statement. Critical Reviews in Food Science and Nutrition, 59 (15), 2411-2422.

Skrovankova, S., Sumczynski, D., Mlcek, J., Jurikova, T., \& Sochor, J. (2015). Bioactive compounds and antioxidant activity in different types of berries. International Journal of Molecular Sciences, 16 (10), 24673-24706.

Zhao, X., Joo, J. C., Kim, D., Lee, J., \& Kim, J. Y. (2016). Estimation of the seedling vigor index of sunflowers treated with various heavy metals. Journal of Bioremediation \& Biodegradation, 7 (3). 